Obituary

Jakob Andersson*

\title{
In Memoriam Åke W. Sjöberg (1924-2014)
}

https://doi.org/10.33063/diva-377933

In the early evening of August 8, 2014, orientalist and Near Eastern philologist Åke Waldemar Sjöberg, Clark Research Professor of Assyriology emeritus, and Curator of the Tablet Collections of the University Museum of Archaeology and Anthropology at the University of Pennsylvania, Philadelphia, USA, passed away peacefully in Uppsala.

Åke was born in Sala, Sweden, on August 1, 1924 to his parents postmaster Bernhard Waldemar Sjöberg and Mary Ingeborg Zetterberg. After primary and secondary schooling in Sala, Åke spent some time as an office worker at a local business, but further studies beckoned him. In 1943, by means of recommendations from friends of the family, he enrolled at Fjellstedtska Skolan, a renowned boarding school in Uppsala. The curriculum at Fjellstedtska had a strong emphasis on biblical studies and on languages, including Latin, Greek, and Biblical Hebrew. Up until 1939, for an application even to be considered, the applicant had to explicitly state that he intended to become a clergyman. In 1946, Åke passed his studentexamen (corresponding to a matriculation examination), granting him access to higher studies. His grade card shows that his strongest subject by far was Biblical Hebrew, for which he received an A - the highest possible grade by the standards of the day.

Later that same year, Åke enrolled at Uppsala University. He attended courses in Semitic Languages led by Professors H. S. Nyberg and Oscar Löfgren; in the History of Religion led by Professor of Old Testament Studies Ivan Engnell; and in Ethnography led by Reader (later Professor) Sture Lagercrantz. In 1950 he completed his first academic degree, filosofie kandidat (Bachelor of Arts) in Semitic Languages, with the other two subjects as minors. This degree was supplemented in 1953 with further course-work: this time in Assyriology, encompassing the Akkadian language in its Babylonian and Assyrian dialects, and the Sumerian language, a linguistic isolate. These ancient languages were written in cuneiform, which is quite different from the alphabetic writing of the languages Ake had been in contact with up to that point. The variety and wealth of source materials for these cuneiform languages are unparalleled among ancient languages. His teacher in Assyriology was, to begin with, Reader Alfred Haldar.

Åke's time at Uppsala University was not all about studies, something he often willingly confessed to. He managed to combine his curricular duties with active participation in the student nation Västmanlands-Dala nation, or V-Dala for short. In 1951-1952, Åke served as klubbmästare (Master of Ceremonies) at V-Dala; and his wife-to-be Gunnil Kronborg was klubbmästarinna (Mistress of Ceremonies). After an intense courtship, the couple married in April 1953. Apart from his duties to the student nation, Åke sang tenor in the student choir, Upsala studentkårs allmänna sångförening, or Allmänna sången. During the mid-1950s, Åke was also a member of a quartet, V-Dala-kvartetten, alongside Gunnar Flodell (baritone), Gunnar Rosenqvist (first bass), and Ragnvald Johannes (second bass). For reasons which are not entirely clear to this author, Sjöberg went under the stage name "Lukas". The quartet was quite successful in its heyday, allegedly almost landing a contract with the Swedish State Radio. Critically acclaimed, they even sang abroad, for instance for the Finnish presidential couple Paasikivi in Helsinki in March 1954. Their repertoire mainly consisted of traditional Swedish student songs, serenades, and international classics. Had it not been for tensions within the

* Department of Linguistics and Philology, Uppsala University, E-mail: Jakob.Andersson@lingfil.uu.se.

Open Access. Published by the Department of Linguistics and Philology, Uppsala University. This work is licensed under the Creative Commons Attribution-NonCommercial-NoDerivatives 4.0 International license. 
quartet, Sjöberg just might have pursued a career in show business, but as it turned out, fate had another path in store for him.

Between 1953 and 1959 Åke spent several semesters in Heidelberg studying Assyriology and Near Eastern Archaeology under Professor Adam Falkenstein at the Orientalisches Seminar, situated by the Karlsplatz in the Heidelberger Altstadt, below Schloss Heidelberg. Sjöberg obtained the degree of filosofie licentiat (roughly corresponding to a Master's degree) in Assyriology in June 1955, with Falkenstein administering the examination. Sjöberg's time in Germany was supported by a substantial grant from H.M. King Gustaf VI Adolf, a keen collector of antiquities who himself had studied archaeology, and who had participated in archaeological excavations in Sweden and the eastern Mediterranean area.

The curriculum in Heidelberg was rigorous. Mondays to Fridays were dedicated to the study of Sumerian and Akkadian cuneiform texts, mostly literary and religious works. Saturdays were completely devoted to studies in Near Eastern Archaeology, a field in which Falkenstein took a particular interest. The reason for this was his involvement as epigrapher during several seasons of excavations in the city of Uruk (modern-day Warka), a substantial settlement that has produced the earliest known stages of writing on clay, massive temple architecture spanning more than 4000 years, and huge numbers of cuneiform tablets and other small finds. Uruk was also the native city of the ancient king Gilgamesh, whose adventures in search of fame and everlasting life became the stuff of later myth.

Falkenstein was a stern critic, but allegedly he was not adverse to handing out words of encouragement when deserved. An academic through and through, it seems Falkenstein had very little understanding for Sjöberg's extracurricular activities, singing traditional German songs for free, accompanied by a pianist in Vater Rhein, an establishment just a stone's throw from the Neckar, and which to this day is still located on the same premises. Between his stints in Heidelberg, and afterwards, Ake taught Hebrew at his old alma mater Fjellstedtska Skolan, and also served as a part-time lecturer at the Department of Theology in Uppsala.

In 1960 Åke successfully defended his doctoral thesis Der Mondgott Nanna-Suen in der sumerischen Überlieferung, 1. Teil: Texte. Shortly after his oral defence, Âke held a lecture for a three-year readership in Assyriology. He went to Stockholm to personally deliver a copy of his thesis to H. M. King Gustaf VI Adolf as a token of gratitude for the financial support he had received during his studies. Although the court secretary told Ake that the king was in, and was expecting him if he would like to pay His Majesty a visit, and although Ake was a committed royalist, he nevertheless declined, saying he did not want to trouble His Majesty. The decision appears to have been taken on the spur of the moment, as later in life he often wondered why he didn't have the nerve to go through that door.

Ake spent the winter of 1961-1962 at Uruk-Warka as a participating guest at the German excavations led by Professor Lenzen. During this time, he travelled quite extensively and saw many other archaeological sites of interest to a specialist in Near Eastern societies, cultures and languages. His observations on these sites are to some extent recounted in one of his early articles in Swedish, "I Sumers städer", (In the Cities of Sumer, Svensk Exegetisk Arsbok 27, 1962, 5-32). It was during this time that Sjöberg picked up the habit of smoking tobacco, while being rescued from the cold winter mornings of a southern Iraqi excavation site. Dressed as if expecting a warm day in the desert, Åke was aided by an experienced sherqati who wrapped his jacket around him, put a cigarette in his mouth, and lit it for him. This episode was one of Sjöberg's favourite anecdotes, and serves as a brilliant illustration of how Åke was not afraid to point to his own shortcomings. It should be added, in all fairness, that for the rest of his smoking career, which lasted a few decades, Ake hardly ever inhaled.

After a few years, Ake was invited to come to the United States. In January 1963, he joined the staff of the Oriental Institute of the University of Chicago, where he assisted in compiling the Assyr- 
ian Dictionary (CAD), a long-standing dictionary project of the Akkadian language in all its dialectal wealth, covering more than 2500 years of written documentation. The CAD project was completed in 2010. In all, Âke and Gunnil spent three years in Chicago before moving to Philadelphia and the University of Pennsylvania in 1966. There Ake began by teaching classes mainly in the Akkadian language. Two years later, Åke succeeded Sumerologist Samuel Noah Kramer as Clark Research Professor in Assyriology, assuming the responsibilities of curator of the tablet collections of the University Museum of Archaeology and Anthropology.

Alongside his colleagues Barry L. Eichler and Erle V. Leichty, both Åke and the department thrived. As an example of the jovial atmosphere at the University Museum can be noted the day when Ake arrived in his office to find that a new volume, bound in red cloth and with gilt lettering on the spine, had been placed on his shelves next to a bound copy of his thesis on the Sumerian moon god. The text on the spine read: Ake Sjoberg - Nanna Suen II; echoing the text on the spine of Åke's bound dissertation: Åke Sjöberg - Nanna-Suen I. When opening the tome, he found it contained several hundred blank pages for him to fill in. Volume II, announced by Sjöberg in his thesis as forth coming, had never materialized, and one of Åke's close colleagues obviously went to great lengths to remind him of this fact. Ake's wife Gunnil also filled a position as lecturer at the same university, teaching Scandinavian Languages alongside courses on Scandinavian culture and literature. Together they entertained scores of visitors, colleagues and friends, from the US and abroad, not least from Sweden, in their home in Philadelphia.

One of Åke's life projects was compiling a set of file cards with lexicographic information on Sumerian words and expressions. The first card was written as early as 1948, after which he worked incessantly on this linguistic treasure trove. The file cards made up the backbone of an ambitious academic undertaking. Some four hundred thousand cards were written, by Åke himself, assistants and students. A first grant application submitted to the National Endowment for the Humanities by Sjöberg and Leichty was rejected. They had simply not requested a large enough sum of money for it to be taken seriously. That mistake was of course rectified in the second application, which was approved. Further contributions were also secured from other institutions and individuals. The resulting project, to create a dictionary of the Sumerian language, the Pennsylvania Sumerian Dictionary, was initiated in 1975. A large measure of inspiration for this project can be ascribed to Åke's days in Chicago as a contributor to the Assyrian Dictionary. Four printed volumes of the dictionary were published before the switch took place to a digital form, the ePSD. The project is being continued by Ake's successor Steve Tinney.

Åke was a member of several learned societies, among others the American Philosophical Society, the American Oriental Society, the Kungl. Humanistiska Vetenskaps-Samfundet i Uppsala, and the Nathan Söderblom Society. In 1971, the University of Pennsylvania awarded him an honorary Master of Arts degree, and in 1994 he was conferred the title of doctor honoris causa in Theology at Uppsala University. He was appointed honorary lifetime member of V-Dala nation in February 1967, but because of his American term schedule, he could not attend the 1st of May dinner at the nation to have his membership formalized. He was not properly installed until May 2004, 37 years later. That same year, he celebrated his 80th birthday at the annual Rencontre Assyriologique Internationale, held in South Africa. And in 2005 the International Association for Assyriology awarded him an honorary membership. In 2010, on the 50th anniversary of his doctorate, he became a doctor jubilaris at the Uppsala University spring doctoral promotions ceremony.

Two Festschrift volumes have been published in Åke's honour: the first to celebrate his 65 th birthday, DUMU E $E_{2}-D U B-B A-A$ (Philadelphia 1989); the second in celebration of his 89th birthday, He Has Opened Nisaba's House of Learning (Leiden and Boston 2014). As a professor, he served as advisor on a number of dissertations. As the curator of the University Museum of Philadelphia tablet collection, he generously granted access and rights to publication of texts in the collection, as witnessed by numer- 
ous notes to this effect in forewords and footnotes strewn across many dozens of publications. The high standard of his philological treatments of literary and religious texts, and his lexicographical expertise in Sumerian and Akkadian are widely acknowledged.

Apart from his dissertation and the four volumes of the Pennsylvania Sumerian Dictionary, Åke published a monograph The Collection of The Sumerian Temple Hymns based on notes and copies made by Eugen Bergmann. The hymns encompass one of the earliest systematizations of Sumerian religious texts. The collection is traditionally dated to around $2300 \mathrm{BCE}$. The redaction of the hymns is commonly attributed to a high priestess of the moon god Nanna-Suen in the city of Ur, princess Enheduana, daughter of king Sargon of Akkad whose capital city figures in the denomination Akkadian, as in the Akkadian language.

Åke also authored scores of academic articles and book reviews in English, German and Swedish treating a wide variety of linguistic and cultural matters related to Near Eastern societies. In addition to his work on the cuneiform languages, one may also note articles on topics related to the Hebrew Bible, such as "Eve and the Chameleon" (In the Shelter of Elyon: Essays on Ancient Palestinian Life and Literature in Honor of G.W. Ahlström, Sheffield 1984, 217-225); and, in Swedish, "Bibel och Babel: En assyriolog läser Genesis 1-3” (Bibel and Babel: An Assyriologist Reads Genesis 1-3, Svensk Exegetisk Årsbok 61 (1996), 7-32). Åke's background in Uppsala, his studies of a wide array of Semitic languages, and his predilection for Biblical Hebrew in particular continued to have a lasting effect on his interests and on his research.

Ake and Gunnil stayed in the United States for over 40 years, but they never applied for American citizenship. Gunnil steadfastly returned to Sweden twice a year to spend time in Uppsala and in Falun, in the province of Dalarna where she was born. Ake often joined her, when his duties allowed. The couple owned a vacation house at Uvnäs, just north of Falun. Åke continued working and publishing research articles long after his retirement in 1996, and in 2004 the couple moved back to Uppsala, where they enjoyed a decade together in a grand apartment overlooking the lush and green Vas aparken. The two never had any children of their own, but they were the godparents of five children. That, along with their extensive social network, made for a busy and rewarding life, inside and outside of academia.

Åke devoured books, with books on historical matters and biographies of politicians, scholars and royalty being his favourites. When time allowed, it was not unusual for him to read a couple of books on such topics in a week. Classical music was one of his and Gunnil's passions, and they often stayed up late to hear a particular concert on the radio. Åke was never one to enjoy athletic activities. The only sport he admitted to having engaged in was swimming, though he did enjoy watching a good game of tennis. Politics did not interest him particularly. He was more keen on discussing statements and policies from different angles, linking them to a historical and modern discourse. He was not a religious man, but as with politics, he enjoyed discussing religious tenets and beliefs, and his sensibilities did not allow for mockery of people of faith.

On August 1, just a week before he breathed his last, Ake celebrated his 90th birthday in the hospital, surrounded by close friends and relations. It was not the kind of celebration that he had planned for, and for which he had requested a specific section of a cuneiform text found at Sultantepe which he had intended to read out to the guests. The passage in question, Sultantepe Tablets no. 400, reverse, lines 45-47, comprises a brief characterization of the life span of a person. As Åke was not able to read it out, a translation is given here:

Forty years means the prime of life, fifty, a life short of days

Sixty years means maturity, seventy, a life long of days

Eighty years means old age, ninety, extreme old age 
Lucid and calm to the end, Ake Waldemar Sjöberg passed away at a respectable age of 90 after a short period of illness, ending a professional career spanning more than half a century. The chapel where his funeral service was held was filled to the brim with friends, relations and colleagues. And in the spirit of Ake, the musical arrangements were chosen with care and performed with great skill.

At the time of his passing, Ake was surrounded by godchildren and a close friend of Gunnil's. Although the world is poorer for losing him, it is all the more rich through the work he has left behind for others to contemplate. It is comforting to know that generations of future scholars will continually turn to his work for reliable editions, evaluations and comments on texts authored in some of the most ancient and obscure languages on record. Åke's spirit will continue to live on in the ongoing unveiling of the oldest historical civilizations in the Near East. We owe him many thanks for making the study of the languages and cultures of the most ancient Near East his career and his prime pastime.

Silim-ma, Åke 